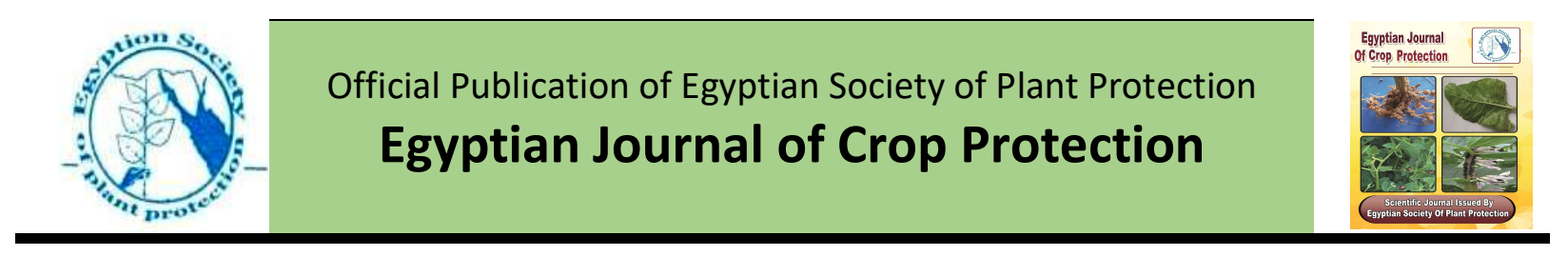

\title{
SURVEY OF ROOT-KNOT NEMATODES MELOIDOGYNE SPP. ASSOCIATED WITH DIFFERENT ECONOMIC CROPS AND WEEDS IN EGYPT
}

\author{
Ramadan Abdelmoneim Bakr ${ }^{*}$, Magdy El-Sayed Mahdy and El-Shawady Mansour Mousa
}

Department of Agricultural Botany, Faculty of Agriculture, Menoufia University, Shebin El-Kom, Egypt

\section{ABSTRACT}

Globally, root-knot nematodes (RKN) recorded as destructive plant pathogen with a wide host range. A field survey of RKN Meloidogyne spp. associated with different vegetable and fruit crops and weeds in sandy and clay soil was carried out in Beheira and Menoufia governorates in Egypt. A total of 81 plant and soil samples were collected and examined. Nematodes extracted from soil samples under laboratory conditions and identified then frequency of occurrence (F.O.\%) and population density (P.D) were calculated. A survey in the selected locations showed remarkable frequency of occurrence and population density of RKN in many vegetable crops and weeds. Results showed that the population density and frequency of occurrence of RKN Meloidogyne spp. were greatly differed in the different crops and different locations. Results showed that frequency of occurrence of Meloidogyne spp. was $100 \%$ in Kom Hamada, Beheira governorate, wheras the population densities recorded between 154-692 J2 / $250 \mathrm{~g}$ soil. Results indicated that Meloidogyne spp. recorded infecting different weeds such as:Common lambsquarters (Chenopodium murale L.), Small bindweed (Convolvulus arvensis), Common purslane (Portulaca oleracea L.) and Solanum (Solanum nigrum). The frequency of occurrence of root-knot nematodes Meloidogyne spp. showed different values in the surveyed locations.

Key words: Plant parasitic nematodes, Root-knot nematodes, Meloidogyne spp., Survey, Host rang.

\section{INTRODUCTION}

Plant parasitic nematodes (PPN) was one of the most hidden destructive enemies infect economic and noneconomic plants all over the world. More than 4100 species of PPN were registered (Decraemer and Hunt, 2006). The losses have been reached $\$$ US80 billion per year (Nicol et al., 2011). The root-knot nematodes (Meloidogyne spp.) registered as one of the most frequently observed ten genera of PPN worldwide *Corresponding author email: ramadanbaker82@agr.Menofia.edu.eg (C) Egyptian Society of Plant Protection.
(Jones et al.,2013). Previous report revealed that genus Meloidogyne consists of about 98 species (Jones et al., 2013) with a host range exceed 3000 plant species from different plant families, causing severe yield losses especially in tropical and sub-tropical agriculture (Sikora and Fernandez, 2005). Recently, Meloidogyne considered as limitation and destructive factor for several crop cultivation (Bakr et al.,2011). Previous survey studies by 
the Egyptian nematologistis revealed that the occurrence of Meloidogyne species associated with different plants belongs to different plant families at different governorates in Egypt (Ibrahim et al., 2000 and 2010; Ibrahim and Handoo, 2015 and 2016.

Those, this study was aimed to survey of Meloidogyne spp. associated with different crops and weeds in sandy and clay soil in two governorates in Egypt.

\section{MATERIALS AND METHODS}

\section{Survey of root-knot nematodes}

Meloidogyne spp. at different crops in different locations.

A comprehensive survey was carried out to know the population density and frequency of occurrence of RKN Meloidogyne spp. associated with different vegetable and fruit crops in different locations. Eighty one samples composed of five sub-samples; each sample was collected from the rhizosphere zone of the different plants at depth $15-30 \mathrm{~cm}$ including a part of plant roots by garden trowel. The five sub-samples mixed well and kept in a polyethylene bag labeled by the most important related data then sealed and sent directly in sample box to the laboratory for nematode extraction and identification process. Nematodes extracted from $250 \mathrm{~g}$ soil sample using serial sieves and modified Baermann technique through 60 and 325 mesh sieves according to Goody (1957). Then resulting suspension transferred to a Baermann pan with a soft tissue filter paper. Three days later the nematodes were counted / $\mathrm{ml}$ of the extraction using the counting slide under a stereomicroscope. Nematode population density (P.D) and frequency of occurrence (F.O) were calculated as revealed by Norton and Varnon deAgudelo (1984) follows the next equations:

$$
\begin{aligned}
& \text { Population Density (P.D) }=\frac{\text { Number of nematodes }}{\text { Total Number of samples }} \\
& \text { Frequency of Occurrence (F.0.\%) }=\frac{\text { Number of positive samples }}{\text { Total Number of samples }} \times 100
\end{aligned}
$$

\section{Occurrence of root-knot nematodes} Meloidogyne spp. on different weeds at different locations.

For the occurrence of RKN Meloidogyne spp. a survey was carried out on different weeds at different locations. Root and soil samples were collected from Chenopodium (Chenopodium album L.), convolvulus (Convolvulus arvensis), portulaca (Portulaca oleracea L.) and solanum (Solanum nigrum L.). Samples were collected in polyethylene bags, labeled, and transferred to the laboratory until use.

\section{-Soil samples:}


Two hundred fifty grams of soil sample were used for nematode extraction by sieving and modified Baermann technique through 60 and 325 meshes according to Goody (1957). Resulting suspension then transferred to a Baermann-pan with a soft tissue filter paper. After 72 hours the extracted second stages juveniles were counted under stereomicroscope.

\section{-Root samples:}

Root samples were examined directly by dissecting the galled root system for the presence of developmental stages or females using stereomicroscope.

\section{RESULTS}

Survey of root-knot nematodes Meloidogyne spp. in different soils and locations.

The nematological survey of Meloidogyne spp. associated with different crops was carried out at different locations in Beheira and Menoufia governorates. Results indicated that RKN populations were greatly differed at the different crops in all examined locations and the symptoms on the different crops were totally different as illustrated in Figs. (13). Data presented in Table (1) showed the population density (P.D.) and frequency of occurrence (F.O. \%) of Meloidogyne spp. on cultivated crops in both of sandy and clay soils.
Results showed that the population density of Meloidogyne spp. were greatly differed in the different crops grown in the sandy soil. The highest recorded population density was found in squash plants by 711 , followed by Jews mallow by 692 and watermelon by 652, whereas the lowest population density was recorded on cabbage plants by 154 second stage juveniles $/ 100 \mathrm{~cm}$ soil in Kom Hamada while, the frequency of occurrence of Meloidogyne spp. was $100 \%$ in all examined samples.

Results from El-Nubaria district cleared that the population density were greatly differed on the different crops. The highest population density was found in faba bean plants by 990 , followed by squash by 856 and banana by 698 whereas the lowest population density was recorded on pepper plants by 111 second stage juveniles $/ 100 \mathrm{~cm}^{3}$ soil whereas, the frequency of occurrence ranged between $75-100 \%$ in all examined samples. Results showed that the population density and frequency of Meloidogyne spp. were greatly differed in the different crops grown in the clay soil in Shebin El-Kom. The highest population density was found in cucumber plants by 500 , followed by tomato by 470 and squash by 469 , whereas the lowest population density 
was recorded on cabbage plants by 117 second stage juveniles $/ 100 \mathrm{~cm}^{3}$ soil. The frequency of occurrence of Meloidogyne spp. in Shebin El-Kom ranged between $60-100 \%$ in all examined samples.

Occurrence of root-knot nematodes Meloidogyne spp. on weeds.

A survey of RKN Meloidogyne spp. associated with weeds was carried out in Shebin El-Kom, El-Nubaria and Kom Hamada. Common lambs-quarters, small bindweed, common purslane and solanum were among the most important weeds in the selected area. Results revealed that the examined weeds are hosts for these nematodes and showed reproduction of Meloidogyne spp.

Table1: Frequency of occurrence and population density of root-knot nematode Meloidogyne spp. on different crops at different locations.

\begin{tabular}{|c|c|c|c|c|c|c|}
\hline \multirow[b]{3}{*}{ Crops } & \multicolumn{4}{|c|}{ Sandy Soil } & \multirow{2}{*}{\multicolumn{2}{|c|}{$\begin{array}{c}\text { Clay Soil } \\
\text { Shebin El-Kom }\end{array}$}} \\
\hline & \multicolumn{2}{|c|}{ Kom Hamada } & \multicolumn{2}{|c|}{ El-Nubaria } & & \\
\hline & ${ }^{*} P . D$ & ${ }^{* *}$ F.O.\% & P. D & F.O.\% & P. D & F.O.\% \\
\hline Tomato & 628.20 & 100 & 693.60 & 100 & 470.50 & 100 \\
\hline Cucumber & $* * *$ & - & 211.50 & 100 & 500.50 & 100 \\
\hline Potatoes & 469.00 & 100 & 548.5 & 100 & 306.25 & 100 \\
\hline pepper & 230.75 & 100 & 111.25 & 75 & 243.75 & 75 \\
\hline Eggplant & 265.00 & 100 & 243.75 & 100 & 155.50 & 100 \\
\hline Squash & 711.40 & 100 & 856.75 & 100 & 469.75 & 100 \\
\hline Cabbage & 154.00 & 100 & - & - & 117.20 & 60 \\
\hline Bean & 342.50 & 100 & 156.50 & 100 & - & - \\
\hline Faba bean & - & - & 990.00 & 100 & 171.50 & 100 \\
\hline Water melon & 656.66 & 100 & 150.5 & 100 & - & - \\
\hline Jews mallow & 692.80 & 100 & 629.25 & 100 & 250.00 & 100 \\
\hline Lettuce & - & - & - & - & 151.00 & 100 \\
\hline Dill & 582.75 & 100 & - & - & 282.75 & 100 \\
\hline Turnip & 368.00 & 100 & 613.33 & 100 & 128.80 & 80 \\
\hline Radish & 270.33 & 100 & - & - & - & - \\
\hline Strawberry & 244.33 & 100 & 256.25 & 100 & - & \\
\hline Banana & 353.33 & 100 & 698.33 & 100 & - & - \\
\hline Grape & 368.40 & 100 & 222.50 & 100 & 123.00 & 100 \\
\hline Citrus(lemon) & 394.25 & 100 & 139.75 & 100 & 269.25 & 100 \\
\hline
\end{tabular}




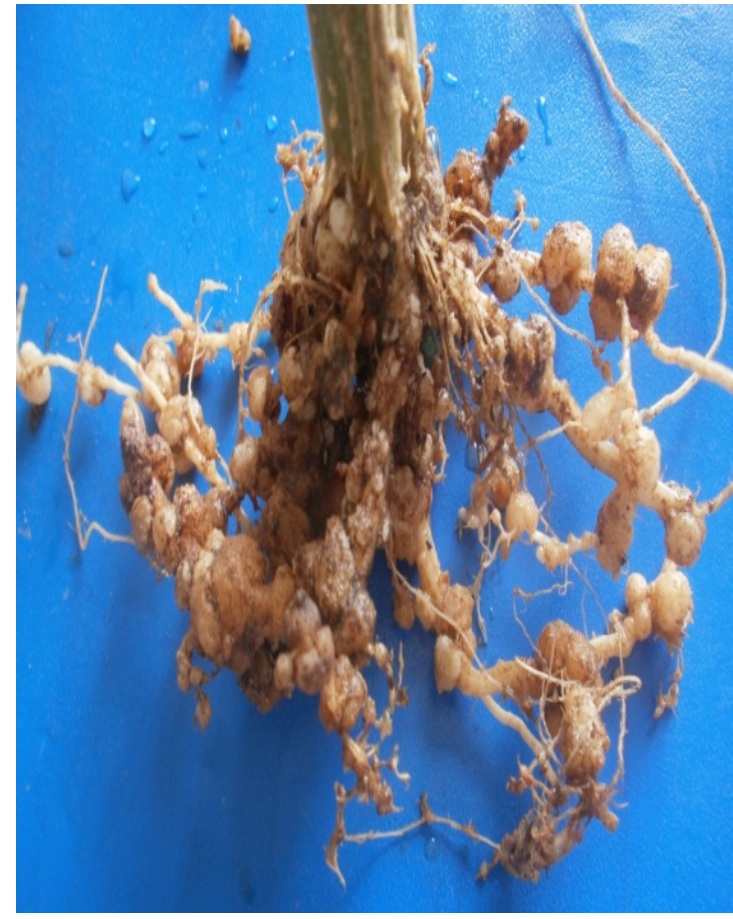

A

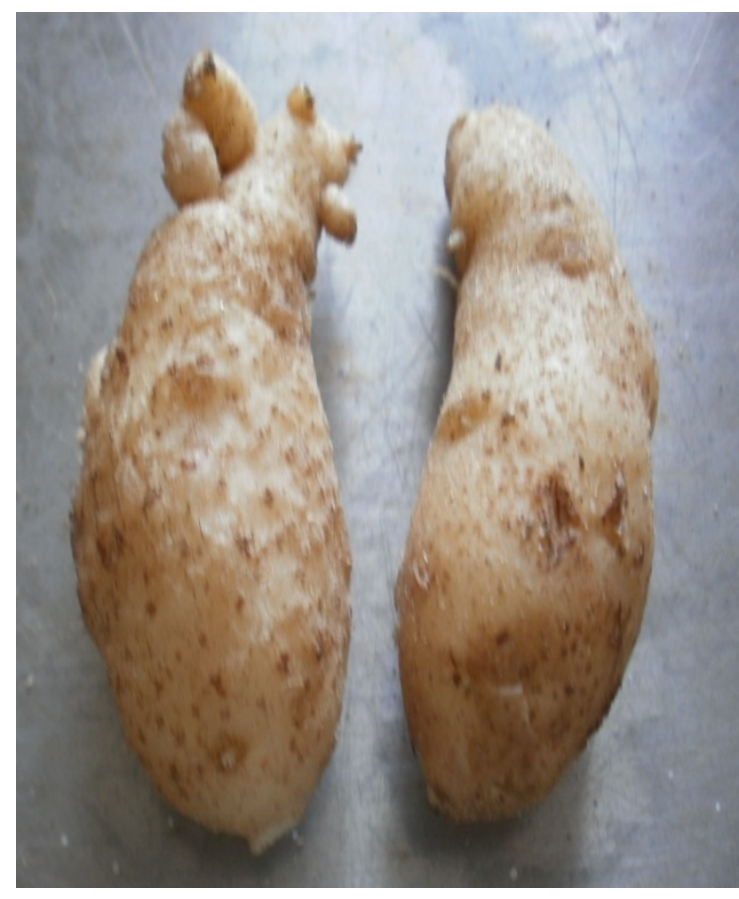

C

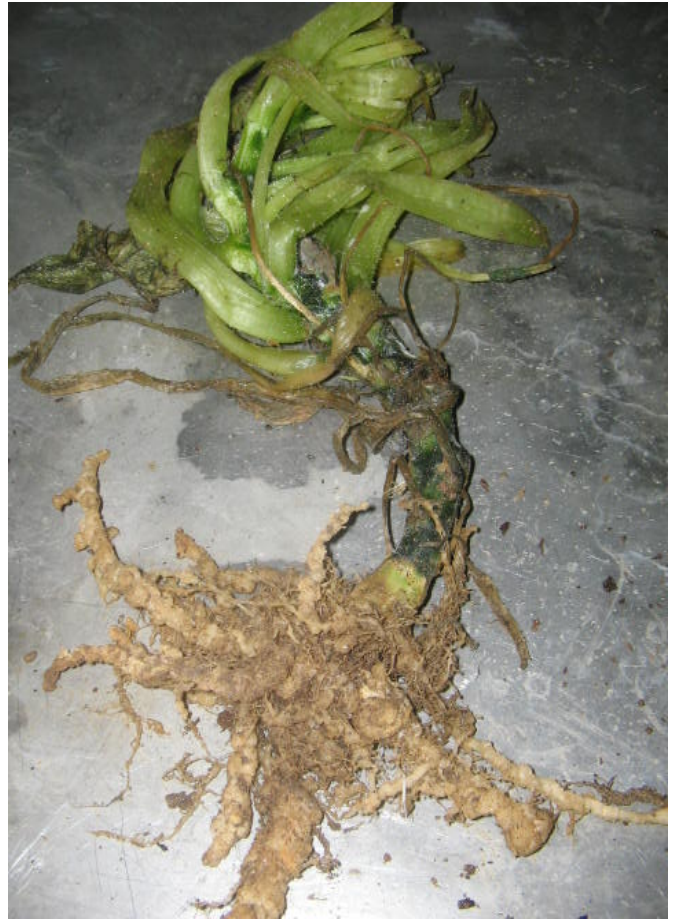

B

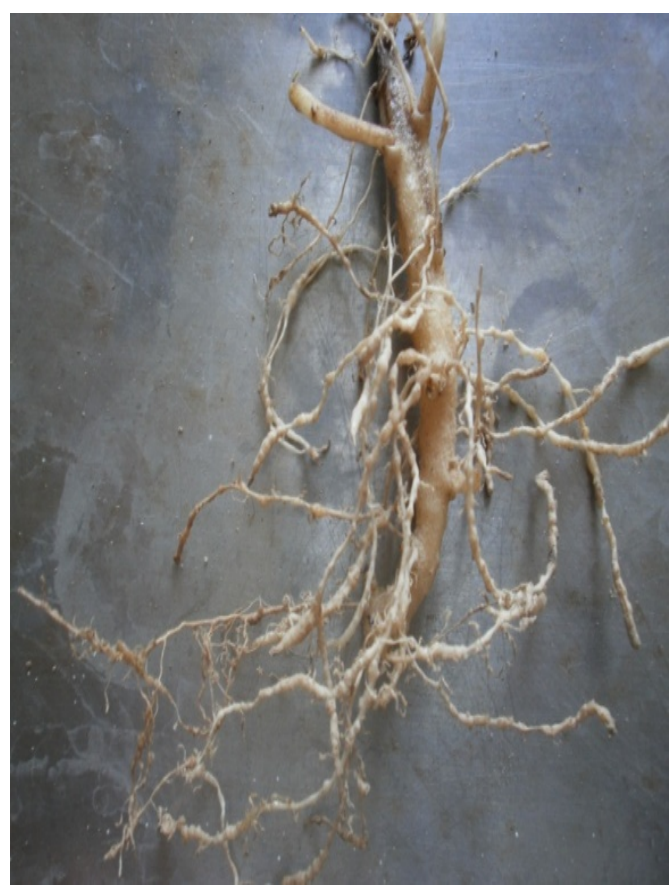

D

Fig.(1):Symptoms of root-knot nematodes disease in three different vegetable crops. A: Cucumber, B: Squash, C: potato tubers and D: Potato roots. 


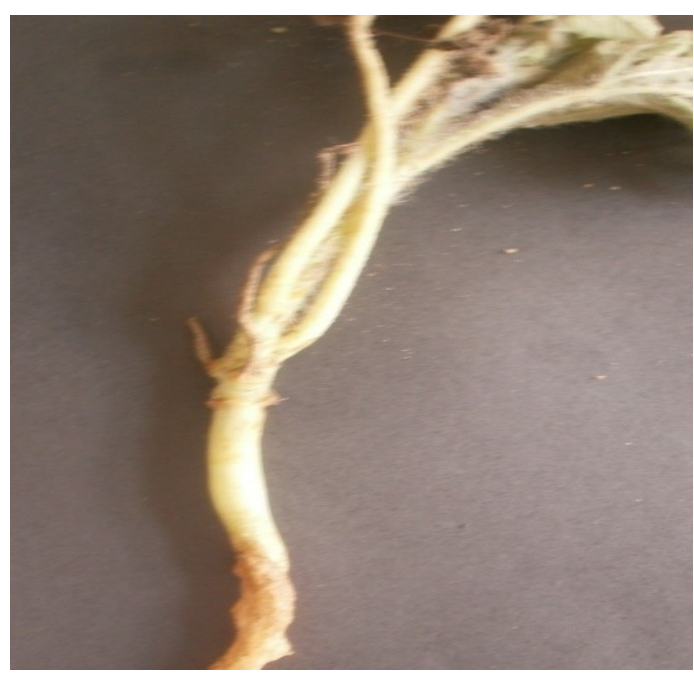

A

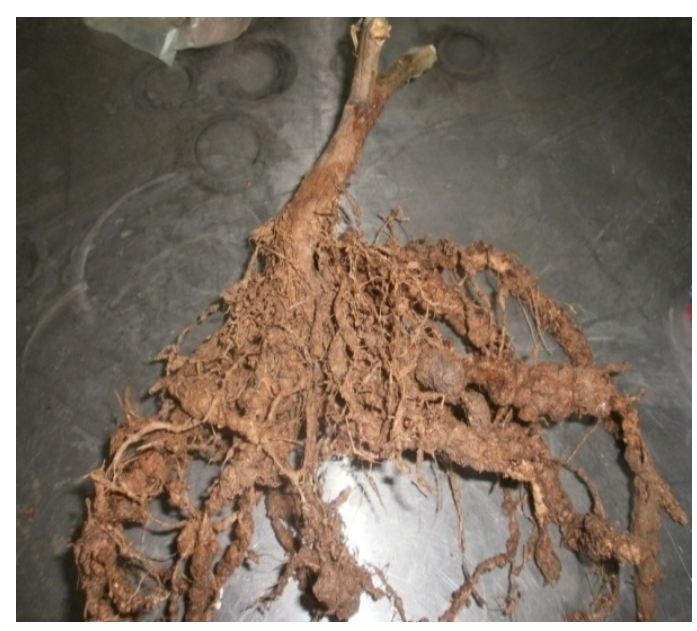

C

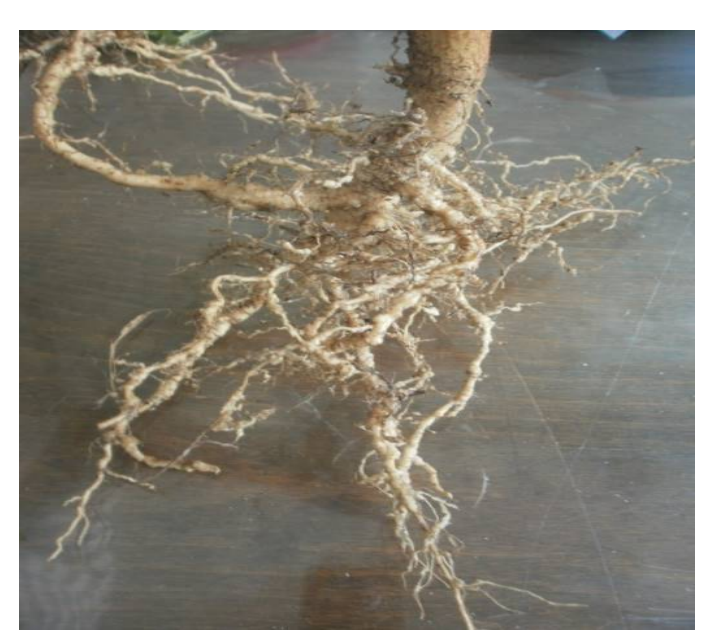

$\mathbf{E}$

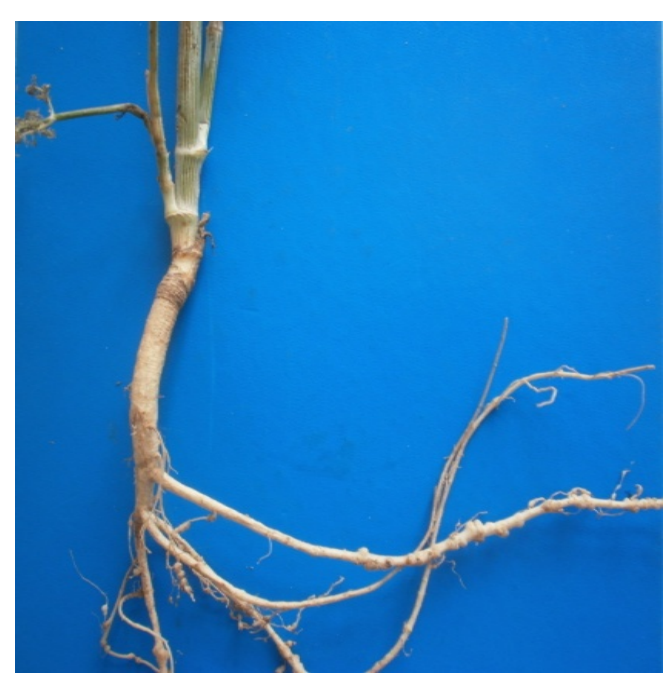

B

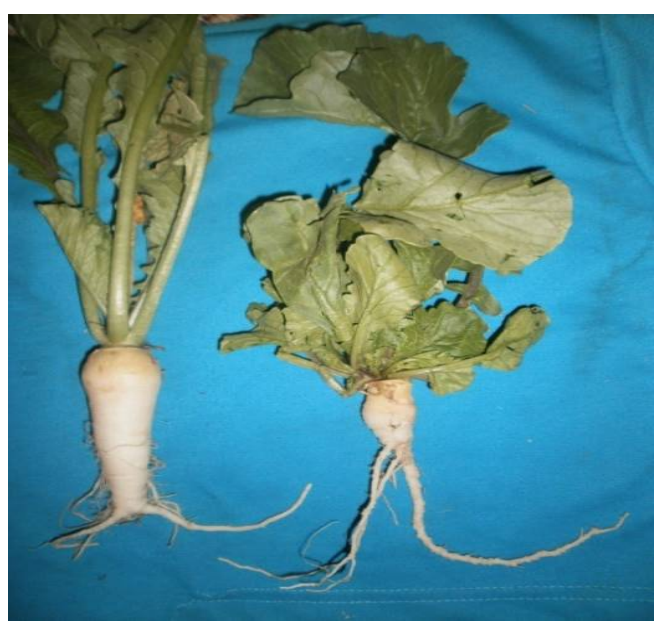

D

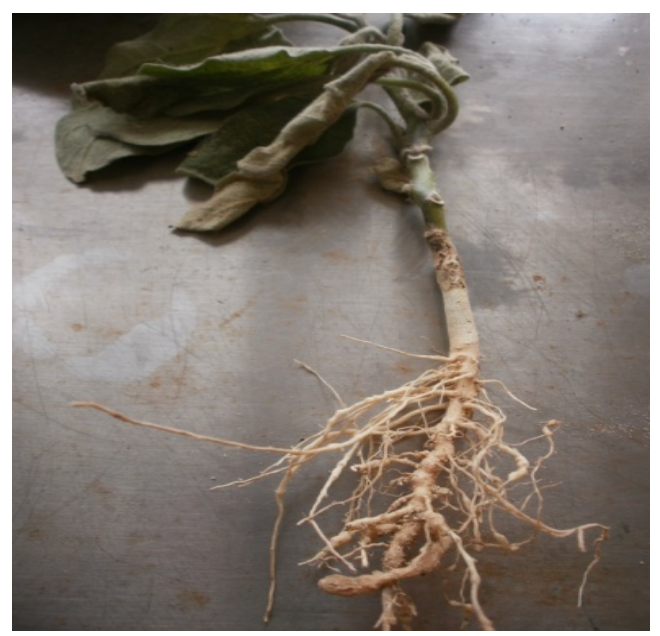

$\mathbf{F}$

Fig.(2): Symptoms of root-knot nematodes disease in different vegetable crops. A: watermelon, B: Dill, C: Tomato, D: Radish, E: Jews mallow and 


\section{F: Eggplant.}

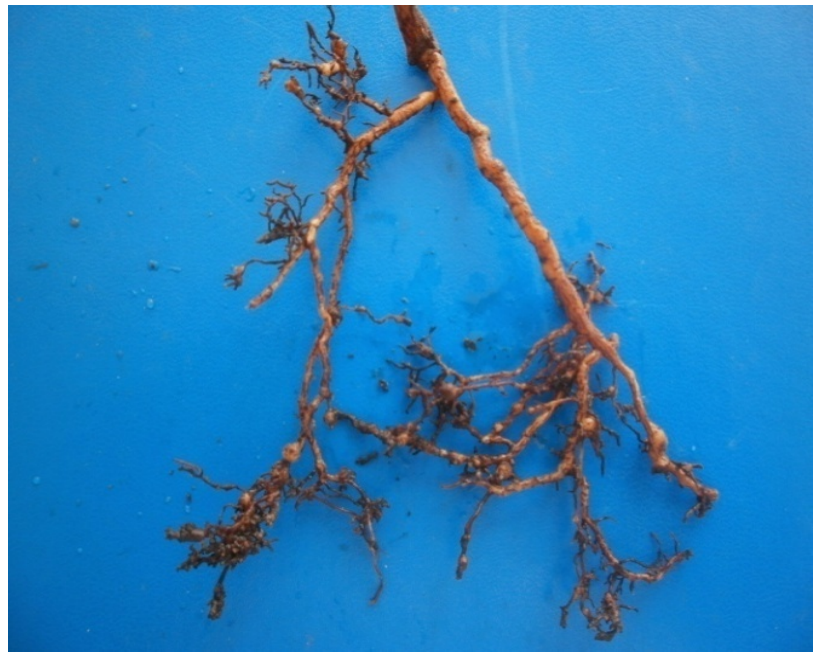

A

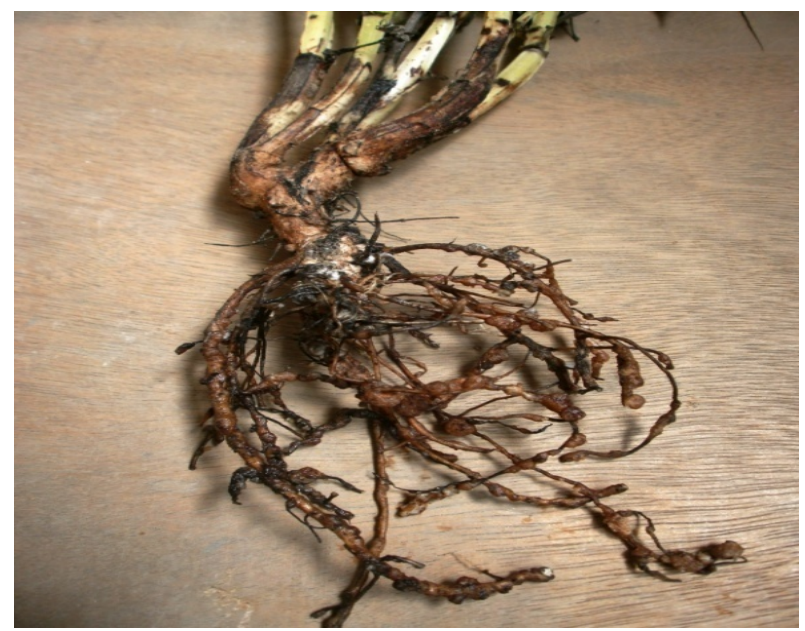

C

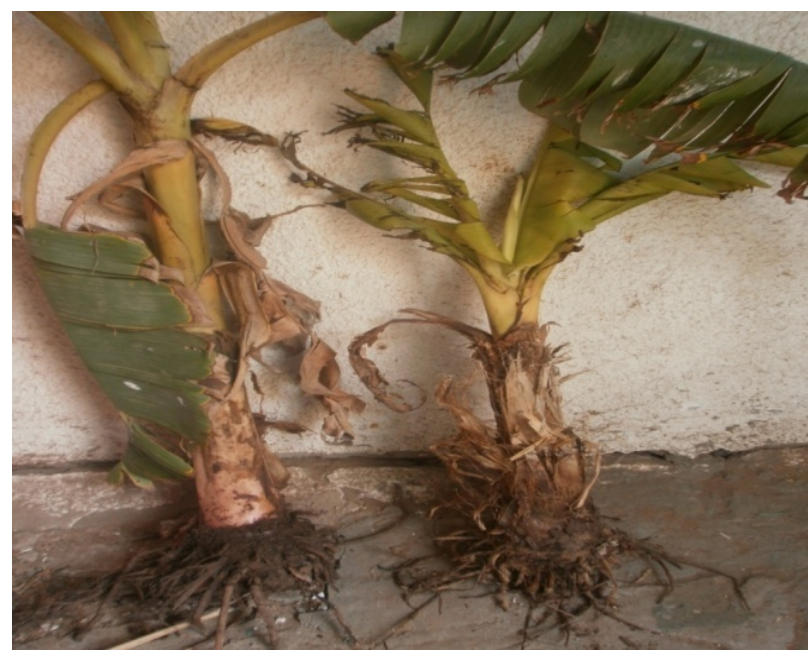

B

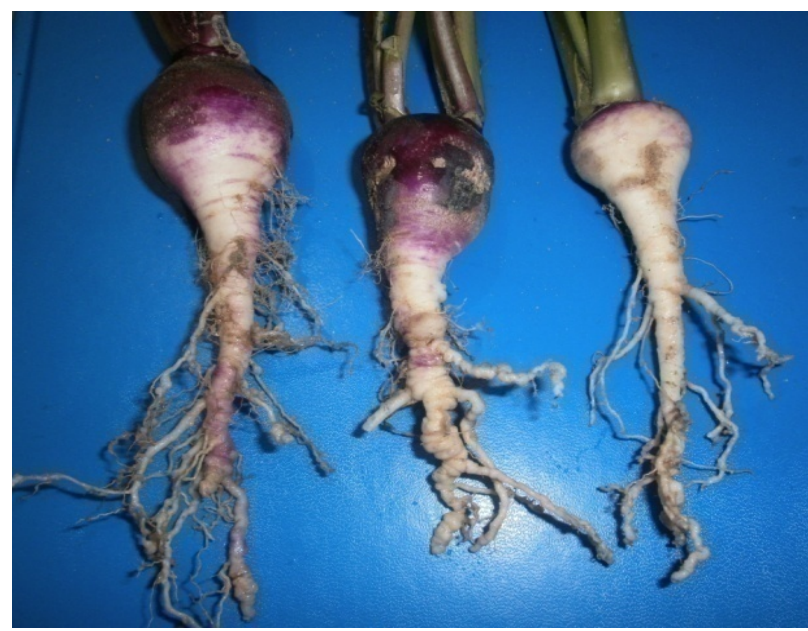

D

Fig.(3): Symptoms of root-knot nematodes disease in different fruit, field and vegetable crops. A: Crap, B: Banana, C: Faba bean and D: Turnip.

Data presented in Table (2) knot nematodes Meloidogyne spp. on indicated that Meloidogyne spp. infect common lambsquarters (Chenopodium the different tested weeds and the murale L.) ranged between $25-90 \%$ in symptoms very clear on the root surveyed locations. The highest system as shown in (Fig.4-5) and the percent was found in El-Nubaria region, frequency of occurrence was differed at followed by Kom Hamada, whereas the all surveyed locations in both soil types. lowest one was recorded in Shebin ElThe frequency of occurrence of rootKom. Observation of small bindweed 
(Convolvulus arvensis) plants collected samples from the selected locations showed different values of frequency of occurrence. The F.0.\% recorded 66.66 and $50 \%$ in El-Nubaria and Kom Hamada, respectively. Small bindweed showed no occurrence of Meloidogyne spp. in Shebin El-Kom. Recorded results cleared that common purslane
(Portulaca oleracea $\quad$ L.) showed different values in its infestation by Meloidogyne spp in the collected samples from the different studied locations. The F.O. \% of Meloidogyne spp in Kom Hamada was the highest one by $62.50 \%$, followed by $50.00 \%$ in El-Nubaria while in Shebin El-Kom was 11.11

$\%$.

Table (2): Frequency of occurrence of root-knot nematodes Meloidogyne spp. on different weeds in both of sandy and clay soil.

\begin{tabular}{|c|c|c|c|c|c|c|c|c|c|}
\hline \multirow[t]{2}{*}{ Weed Name } & \multicolumn{3}{|c|}{ Shebin El-Kom } & \multicolumn{3}{|c|}{ El-Nubaria } & \multicolumn{3}{|c|}{ Kom Hamada } \\
\hline & 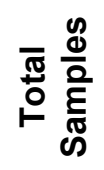 & 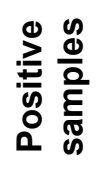 & $\begin{array}{l}\stackrel{0}{0} \\
\dot{0} \\
*\end{array}$ & 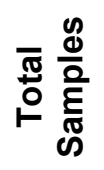 & 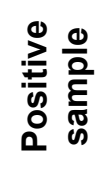 & $\begin{array}{l}\text { ¿̊ } \\
\dot{0}\end{array}$ & 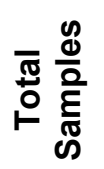 & 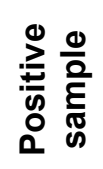 & $\begin{array}{l}\stackrel{0}{0} \\
\dot{0}\end{array}$ \\
\hline $\begin{array}{l}\text { Common lambsquarters } \\
\text { (Chenopodium murale L.) }\end{array}$ & 12 & 3 & 25.00 & 10 & 9 & 90.00 & 9 & 6 & 66.66 \\
\hline $\begin{array}{c}\text { Small bindweed } \\
\text { (Convolvulus arvensis) }\end{array}$ & 6 & 0 & 00.00 & 9 & 6 & 66.66 & 8 & 4 & 50.00 \\
\hline $\begin{array}{c}\text { Common purslane } \\
\text { (Portulaca oleracea L.) }\end{array}$ & 9 & 1 & 11.11 & 6 & 3 & 50.00 & 8 & 5 & 62.50 \\
\hline $\begin{array}{c}\text { Solanum } \\
\text { (Solanum nigrum) }\end{array}$ & 6 & 4 & 66.66 & 8 & 7 & 87.50 & 15 & 11 & 73.33 \\
\hline
\end{tabular}

${ }^{*} \mathrm{~F}$.O. $=$ Frequency of Occurrence

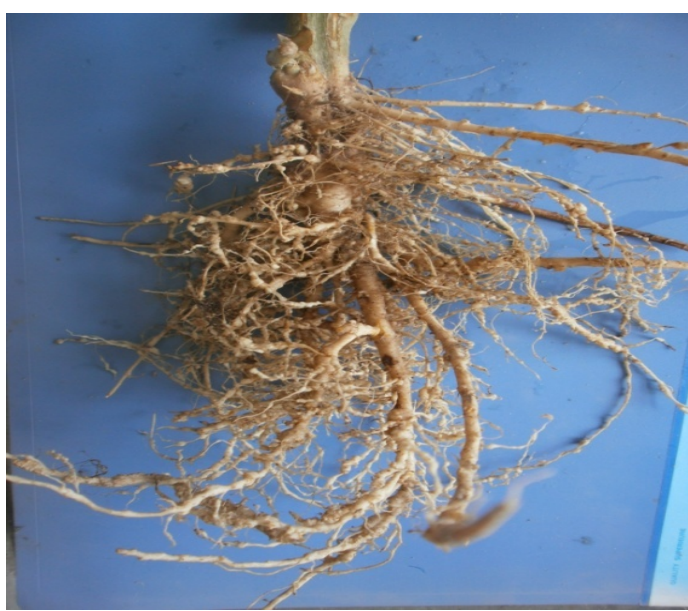

A

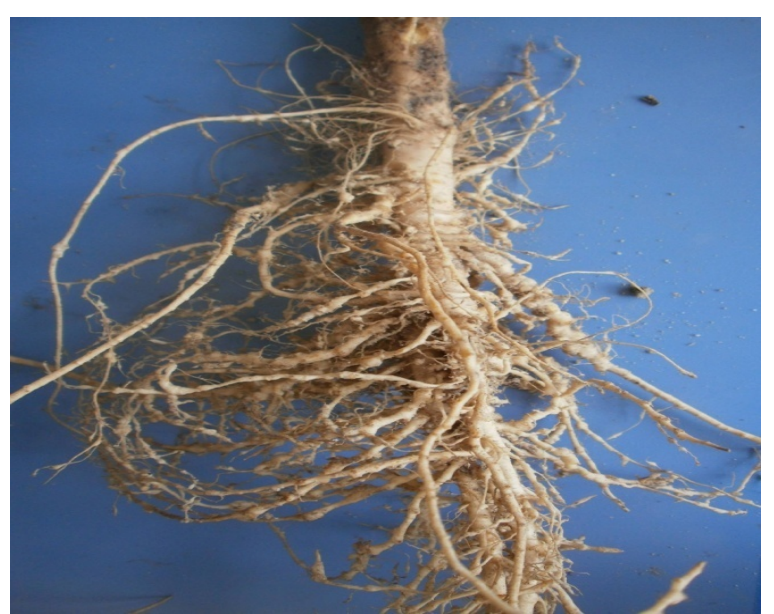

B

Fig.(4):Symptoms of root-knot nematodes disease on different weeds. A,B: Common lambsquarters. 


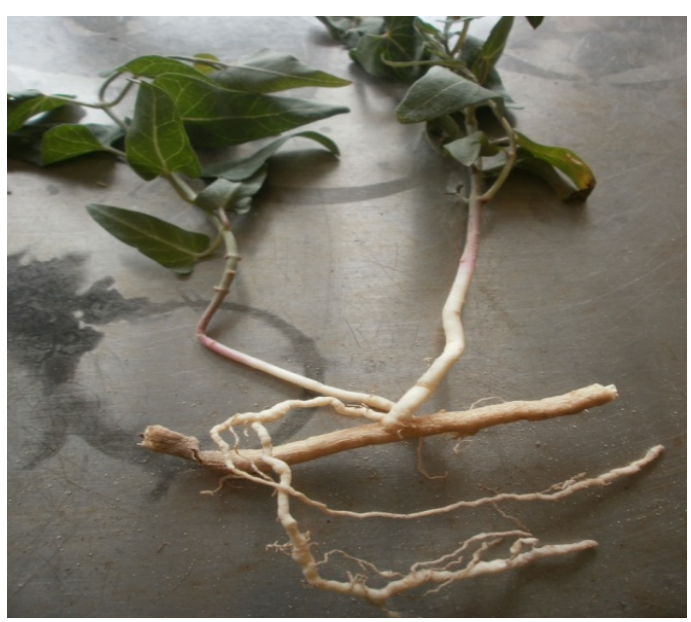

A

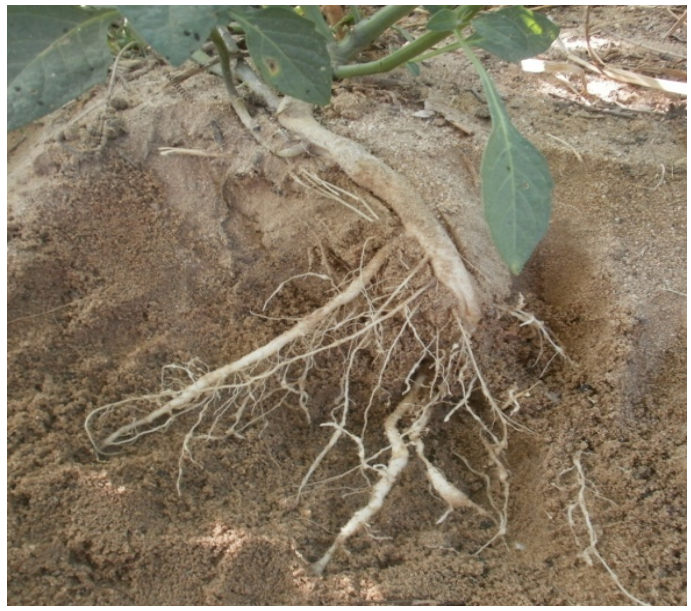

C

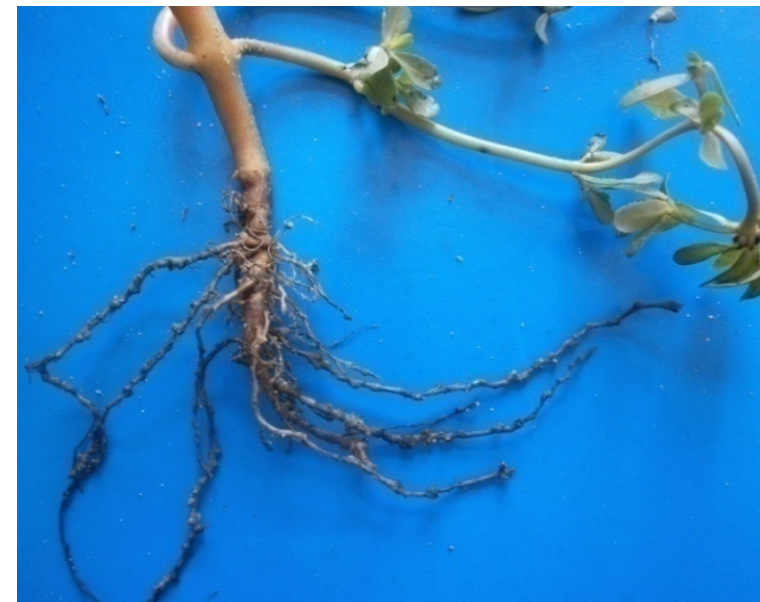

B

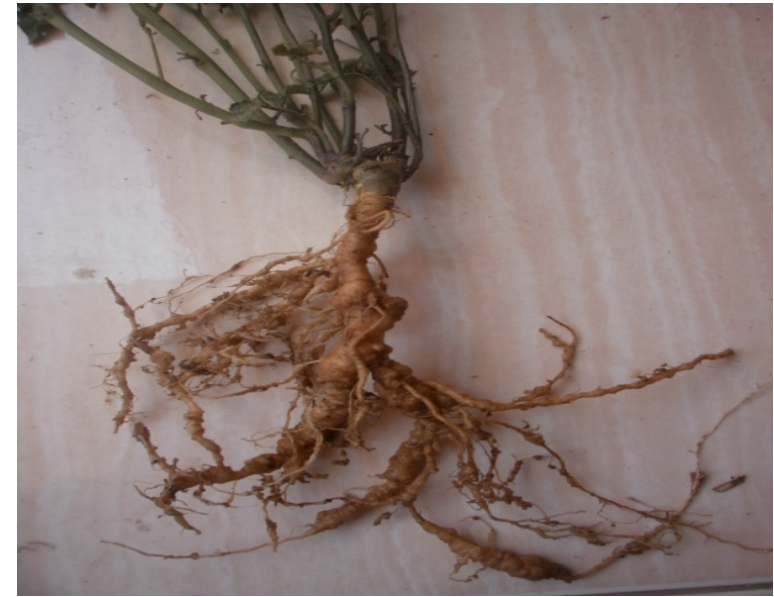

D

Fig.(5):Symptoms of root-knot nematodes disease on different weeds. A: Small bindweed, B: Common purslane and C,D: Solanum.

\section{DISCUSSION}

Survey results showed the differences between population densities and frequencies of the RKN Meloidogyne spp. occurrence in the surveyed locations. Data showed that Meloidogyne spp. is associated with the most examined plants and this in agreement with Anwar et al., (1991) and Bakr,(2014), who stated that
Meloidogyne spp. were the major nematodes of vegetables such as tomato, okra, chillies and cucurbits. Meloidogyne spp. were the most common nematodes in potato, tomato and watermelon and this in agreement with those obtained by Mokbel et al., (2006) and Bakr et al., (2011), who reported that Meloidogyne spp. were 
the most common nematodes in potato, tomato, and watermelon soil samples with $11-57 \%$ frequency of occurrence, and population densities ranged between 190-827 nematodes/250g soil. Banana soil samples showed a higher number of second stage juveniles of Meloidogyne spp. with $100 \%$ frequency of occurrence and this may be attributed to the status of banana as a prefered host for Meloidogyne spp. as reported by El-Nagdi (2001) and Heikal (2001). In a survey by Korayem et al., (2014), found Meloidogyne sp. associated with different crops such as, Broad bean, Eggplant and Tomato as recorded $27.6,33.3$ and $48.1 \%$ of frequency during survey in Sahl ElTeina, El-Sheikh Zowaiid and Beer ElAbd respectively. Also, El-Sagheer (2020), reported that Meloidogyne was the most prominence value (17.20 and 19.80) on banana in Abo-Teg and East Mangabad in Egypt. The higher different in the population density in the examined locations may be referred to different factors such as location, soil type, irrigation system, soil moisture, kind of cultivated crops, climate and agricultural practices and this is in agreement with those obtained by Aballay et al., (2009) as they reported that management practices or environmental factors greatly influenced nematode populations. Soil structure and texture has been pointed out as regulating the spatial patterns of soil nematodes by affecting the size of soil pores and the existence of stable compound aggregates. Coarse structures and well-structured soils are suitable factors for a faster population growth, especially at field level (Avendaño et al., 2004). According to Popovici and Ciobanu (2000), variations in nematodes communities composition in the soil could explain by many factors such as, soil $\mathrm{pH}$, total nitrogen, humus content and exchangeable bases. Earlier studies by Mousa (1997) Ibrahim et al., (2000), Ibrahim et al, (2010) and Bakr et al., (2011) revealed that infection and highest distribution of Meloidogyne spp. occurred in sandy soil especially in the new reclaimed lands and depend on the kind of cultivated crops and temperature. The continuous of growing local cultivars and continuous cropping practice favor survival and rapid build-up of nematode populations in the soil (Ibrahim et al., 2000 and Basyony et al.,2020). This survey covers the most important crops grown in the selected area and showed the population density and the frequency of occurrence of Meloidogyne spp. which provide the importance of this causal 
organism on the disease symptoms (root galling, yellowing, poor growth, etc.) and the lower production of these crops which will affect the economic income. So that, farm must be examined before planting for nematode infestation, population density and frequency of occurrence of Meloidogyne spp. which consequently help the farmer to choose the best cultivar, sowing date, control programs. Furthermore, providing good information about host range of Meloidogyne will provided a chance for selection an efficient crop rotation.

Weeds consider as a problem, because weeds compete the economic crops for nutrients, water, space and light which reduce crop growth and yield. Weeds also serving as a reservoir, secondary host or transport for diseases (Gonzalez et al., 1995 and Ramappa et al., 1998). Common lambs-quarters, small bindweed, common purslane and solanum were among the most important weeds in the selected area. Results clear that the occurrence of RKN Meloidogyne spp. on the selected different weeds in the examined locations were different. Weeds causing not only damage and losses in the crops production but also consider as hosts to root-knot nematodes during the growing and fallow season of the main crops and this in agreement with Bélair and Benoit,(1996) and Venkatesh et al., (2000). A wide range of weed plants associated with vegetable crops are reported as excellent hosts for Meloidogyne spp. (Bélair and Benoit,1996) and Rich et al., (2009). Weeds presences allow the building-up of the nematode's population in the soil. The differ in the frequency of occurrence in the selected area may be revealed to the different in the soil type which affect the root system spread in the soil.

Also, the absence of the cultivated crops give nematode the important to migrate towards the weeds root system until the next crop sowing in the same soil. Therefore, exclusion of such weeds could efficiently prevent main crops from nematode infestation. Noling and Gilreath (2002), reported that controlling love-lies-bleeding (Amaranthus spp.) was essential method for limiting nematode population, because this plant register as good host for RKN Meloidogyne spp..Delay or ignore weed control in fallows could help in increase nematode population levels (Schroeder et al., 1993). Kutywayo and Been (2006) and Rich et al., (2009), reported 
that inadequate weed control can counteract with nematode control strategies, such as resistant crops and fallows. So, weeds control is very important for nematode agricultural control methods and must be included in the integrated control program strategy.

\section{References}

Aballay, E., P. Persson, and A. Martensson (2009) Plant-parasitic nematodes in chilean vineyards. Nematropica, 39:8597.

Anwar, S. A., S.Gorsi, M. Hag-ul. Anwar, T. Rehman and P. Yousuf (1991). Plant parasitic nematodes of some field, vegetable, fruit and ornamental crops. Journal of Agricultural research Lahore, 29(2):233-249.

Avendaño, F., J. P. Pierce, O. Schabenberger, and $\mathrm{H}$. Melakeberhan (2004). Spatial variability: The spatial distribution of soybean cyst nematode in relation to soil texture and soil map unit. Agronomy Journal, 96:181-194.

Bakr, R.A. (2014). Mechanism of some biocontrol agents and plant extracts to control root-knot nematode disease. Ph.D. Thesis. Faculty of Agriculture, Menoufia University, Egypt.

Bakr, R.A., M.E. Mahdy and E.M. Mousa (2011). A Survey of Root-knot and Citrus Nematodes in Some New
Reclaimed lands in Egypt. Pakistan Journal of Nematology, 29(2):165-170.

Basyony, A., I. K. Ibrahim, S. Zeyadah, and M. A. Kawanna (2020). Survey of Plant Parasitic Nematode Associated with Spinach, Swiss Chard and Table Beet in North Egypt. Alexandria Science Exchange Journal, 41: 471-477.

Bélair, G. and D.L. Benoit (1996). Host suitability of 32 common weeds to Meloidogyne hapla in organic soils of southwestern Quebec. Journal of Nematology. 28: 643-647.

Decraemer, W. and D.J. Hunt (2006). Structure and classification. In: Plant Nematology (Perry, R.N. and Moens, M., eds), pp. 3-32. Wallingford, Oxfordshire: CAB International.

El-Nagdi, W.A. (2001). Studies on banana nematodes in Egypt. Ph.D. Thesis, Fac. of Agric., Cairo Univ., Egypt.

El-Sagheer, A.M. (2020). Status of phytonematodes in a main commercial banana production of upper Egypt. Pakistan Journal of Nematology, 38(2): 156-160.

Gonzalez Ponce, R., C. Zancada, M. Verduga, and L. Salas (1995). The influence of the nematode Meloidogyne incognita on competition between Solanum nigrum and tomato. Weed Research. 35:437-443.

Goody,J.B.(1957).Laboratory method for work with plant and soil nematodes. 
Ministry of Agric., Fisheries and food:

Tech. Bull.2. London, England,44p.

Heikal, H.M. (2001). Pathological and biological studies on parasitic nematodes affecting banana in Egypt. M.Sc. Thesis. Fac. of Agric., Damanhour, Alexandria Univ., Egypt.

Ibrahim, I. K. A., A. A. Mokbel and Z. A. Handoo (2010). Current status of phytoparasitic nematodes and their host plants in Egypt. Nematropica, 40:239262.

Ibrahim, I. K. A., Z. A. Handoo and A. A. El-Sherbiny (2000). A survey of phytoparasitic nematodes on cultivated and non-cultivated plants in north western Egypt. Journal of Nematology, 32(4s):478-485.

Ibrahim, I. K. A. and Z. A. Handoo. (2015).

Survey of phytoparasitic nematodes associated with some crop plants in northern Egypt. Journal of Nematology. 47(3): $247-250$.

Ibrahim, I. K. A. and Z. A. Handoo. (2016).

Occurrence of phytoparasitic nematodes on some crop plants in northern Egypt. Pakistan Journal of Nematology. 34(2): 163 - 169.

Jones, J.T., A. Haegeman, E.G. Danchin, H.S. Gaur, J. Helder, M.G. Jones, T. Kikuchi, R. Manzanilla-López, J. E. Palomares-Rius, W.M. Wesemael and R.N. Perry (2013). Top 10 plant-parasitic nematodes in molecular plant pathology. Molecular Plant Pathology, 14(9), pp.946-961.

Korayem, A.M., M.M.A. Youssef, M.M.M. Mohamed, and A.M.S. Lashein, (2014). A Survey of Plant Parasitic Nematodes Associated with Different Plants in North Sinai. Middle East Journal of Agriculture Research, 3(3): 522-529.

Kutywayo, V. and T.H. Been (2006). Host status of six major weeds to Meloidogyne chitwoodi and Pratylenchus penetrans, including a preliminary field survey concerning other weeds. Nematology, 8: 647-657.

Mokbel, A.A., I.K.A. Ibrahim, M.A.M. ELSaedy and S.E. Hammad (2006). Plant Parasitic Nematodes Associated with some Fruit Trees and Vegetable Crops in Northern Egypt. Egyptian Journal of Phytopathology., 34(2): 43-51.

Mousa, E.M. (1997). Geographical distribution of root-knot nematodes and their threats to agriculture in Egypt. Proceedings of the first international workshop of Afro-Asian Nematologistes, Menoufia, Egypt, Jun 8-13, 1997:49-56. Nicol, J.M., Turner, S.J., Coyne, D.L., den Nijs, L., S. Hockland and Z.T. Maafi (2011) Current nematode threats to world agriculture. In: Genomics and Molecular Genetics of Plant-Nematode Interactions (Jones, J.T., Gheysen, G. and Fenoll, C., eds), pp. 21-44. Heidelberg: Springer. 
Noling, J.W. and J.P. Gilreath (2002). Weed and nematode management: simultaneous considerations. In: Gobenauf, G.L. (Ed.), Annu. Int. Res. Conf. on Methyl Bromide Alternatives and Emissions Reductions Orlando, FL (USA).

Norton, D.C. and F. Varon de Agudelo (1984). Plant-parasitic nematodes associated with Maize in Cauca and Valle del Cauca, Colombia. Plant Disease, 68:950-952.

Popovici, I. and M. Ciobanu. (2000). Diversity and distribution of nematode communities in grasslands from Romania in relation to vegetation and soil characteristics. Applied Soil Ecology, 14:27-36.

Ramappa, H. K., V. Muniyappa and J. Colvin (1998). The contribution of tomato and alternative host plants to tomato leaf curl virus inoculum pressure in different areas of south India. Annales of Applied. Biology. 133:187-198.

Rich, J.R., J.A., Brito, R. Kaur and J.A. Ferrell (2009). Weed species as hosts of
Meloidogyne: a review. Nematropica, 39: 157-185.

Schroeder, J., S.H. Thomas and L. Murray (1993). Yellow and purple nutsedge and chile peppers host southern root-knot nematode. Weed Science. 41: 150-156.

Sikora, R. A. and E. Fernandez (2005). Nematode parasites of vegetables, Luc M., Sikora RA, and Bridge J. (Eds.), Plant parasitic Nematodes in Subtropical and Tropical Agriculture. Wallingford, UK: CABI Publishing.

Venkatesh, R.; S. K. Harrison and R. M. Riedel (2000). Weed hosts of soybean cyst nematode (Heterodera glycines) in Ohio. Weed Technology. 14:156-160.

Received: September 30, 2020.

Revised: December10, 2020.

Accepted: December 25, 2020.

\section{How to cite this article:}

Bakr, R.A.; M.E. Mahdy and E.M. Mousa (2020). Survey of root-knot nematodes Meloidogyne spp. associated with different economic crops and weeds in Egypt. Egyptian Journal of Crop Protection, 15(2): 1-14. 